\title{
ПСИХОЛОГІЧНИЙ АНАЛІЗ ФАКТОРІВ, ЯКІ ВПЛИВАЮТЬ НА ХАРЧОВУ ПОВЕДІНКУ ЛЮДИНИ
}

УДК: 159.923

\section{Абсалямова Лариса Миколаӥвна}

Кандидат психологічних наук, доиент, доиент кафедри практичної психології, Національний педагогічний університет імені Г. С. Сковороди, м. Харків (Україна)

\begin{abstract}
Анотація. У статті представлений психологічний аналіз факторів, які впливають на харчову поведінку та харчові вибори людини. Вивчаються різні фактори впливу на харчову поведінку особистості, від психофізіологічних до соччіальних та культурних. Наголошується на довготривалості харчової поведінки людини, ї̈ необхідності в щзоденному житті, $і$, відповідно, значущцості для психологічного благополуччя особистості. Аналізується такий фактор впливу на харчову поведінку, як культурні ичінності. Це виводить дослідження в простір сучасних тенденцій психологічної науки, в межах якої важливо враховувати культурно-історичні детермінанти.

Досліджуються такі фактори, як сприйняття, установки, переконання та иінності. Це пов'язує досліджувану проблематику не тільки із досягненнями когнітивної психологї, але й фактично виводить в простір реального життя людини та психологічної допомоги особистості, внутрішньо готової до змін в харчовій поведінці. Робиться висновок про необхідність врахування різних факторів впливу на харчову поведінку людини в прочесі психологічної роботи професіонала з особистістю, яка вирішила змінити певні аспекти власної харчової поведінки $і$ тим самим оптимізує своє психологічне здоров'я та благополуччя.
\end{abstract}

Ключові слова: харчова поведінка, особистість, харчовий вибір, розлади харчової поведінки, зміни харчової поведінки.

Постановка проблеми. Ціла низка факторів, від біологічних до антропологічних, взаємодіють у складний та мінливий спосіб, впливаючи на розвиток та підтримку харчових виборів людини. Розуміння поведінкових впливів у ширшому контексті психосоціальних взаємодій є ключовим для розробки дієтологічних настанов, методик харчування та просвітницьких закликів, які допомагають споживачам вибудовувати оптимальні систе- 
ми харчування та просувати здорові харчові зміни у власному житті. Для правильного вибору цілей цих харчових змін, для модифікації підставових особистісних переконань та патернів поведінки важливо знати та розуміти точки критичного впливу на харчовий вибір людини.

Історично підхід у охороні громадського здоров'я щодо харчових змін спирався на припущення, нібито споживачі для запобігання потенційним хворобам самі відмовлятимуться від таких форм харчової поведінки, які є вочевидь нездоровими [2]. Хоча теза про те, що знання впливає на поведінку, може здаватися самоочевидною, однак насправді навіть широке публічне надання інформації про ті чи інші харчові ризики не справляє помітного ефекту на харчову поведінку аж доти, поки не проламає увесь комплекс психологічних, поведінкових та соціальних захисних бар'єрів. Аби харчові зміни були настільки простими, як це може здаватися на перший погляд, тоді просте поширення інформації призводило би до поведінкових змін, що аж ніяк не відбувається саме по собі практично у будь-якій харчовій поведінці.

Харчова поведінка безперервно набувається протягом усього життя людини, і тому зміни у такій поведінці вимагають формування повторюваних звичок, які мають бути так само тривалими; така тривалість є принципово більшою за будь-які короткотермінові періоди інтервенцій [3]. Дієтологічні настано- ви, спрямовані на зменшення споживання жирів, часто спонукають до уникання окремих продуктів чи навіть цілих харчових категорій, і відтак здебільшого сприймаються як надмірно обтяжливі. Одноманітні дієти мають додатковий недолік виразного несмаку, який перетворюється на постійне відчуття незадоволеності та неповноти відчуттів. Більше того, вони можуть виявитися несумісними 3 національними чи сімейними стандартами належного споживання їжі. Харчові зміни можуть потребувати більше коштів, знань, умінь, часу та зусиль на приготування їжі. Фактори оточення, такі як груповий тиск, реклама та інші культурно обумовлені чинники можуть категорично протистояти рекомендованим харчовим змінам. Соціальні та політичні цінності та економічні міркування, насамперед доступність продуктів до придбання, також можуть стати значними перешкодами на шляху до втілення бажаних харчових змін [6]. Сполучені докупи, ці перешкоди призводять до того, що дієтологічні настанови виявляється набагато легше висловлювати, аніж приймати та дотримуватися.

Для ілюстрації труднощів, 3 якими стикається людина на початку харчових змін, розглянемо такий приклад: 50-річна жінка дізнається, що іiі традиційний харчовий вибір молока 3 жирністю 2 \% не є настільки нежирним, як вона звикла вважати, і відтак вирішує перейти на знежирене молоко. Більшість людей вважатиме це простою поведінковою змі- 
ною, однак насправді це доволі складний процес. По-перше, вона має знайти магазин, який продає знежирене молоко. Якщо у іiї звичному магазині такого молока нема, жінка має або змінити магазин або вимагати доступності такого продукту у «своєму» магазині. Якщо інші члени родини віддають перевагу іншим різновидам молока, їй доведеться відводити більший обсяг холодильника під зберігання молочних продуктів, відкладати більше грошей на придбання кількох видів молока, враховувати, чи зможе вона готувати звичні родинні страви на знежиреному молоці та як вона може купити знежирене молоко на роботі. Йдеться про те, що показово проста, одинарна зміна харчової поведінки супроводжується великою кількістю супутніх рішень та виборів людини у різноманітних життєвих сферах. Більше того: перед тим, під час того і навіть після того, як людина прийме важливе рішення про зміну харчової поведінки, позитивні наслідки мають постійно переважати усю суму різноманітних перешкод до втілення та підтримки цієї зміни. Чим більшою є кількість факторів, залучених до поведінкової зміни, тим більшою $є$ кількість потенційних перешкод i тим важче втілити та надалі підтримувати заплановану зміну харчової поведінки.

На початку нашого дослідження ми покажемо поведінкові та соціальні впливи на харчовий вибір, потім зробимо огляд наявних досліджень щодо того, як соціальні, групові, поведінкові та індивідуальні впливи співвід- носяться 3 харчовими змінами [4]. Насамкінець буде визначено перспективи подальших досліджень та наукових розробок.

Мета статті - презентувати результати теоретичного аналізу факторів, які впливають на харчову поведінку людини.

Аналіз останніх досліджень i публікацій. Більшість наукових та дослідницьких праць 3 проблематики харчових виборів зосереджуються на фізіологічних та психологічних детермінантах, звертаючи виразно меншу увагу на культурні, історичні, соціальні та демографічні аспекти. Численні дослідження детермінантів харчового вибору сукупно містять великий метамасив розрізнених даних, що потребують інтеграції та систематизації на різних рівнях. Подальші дослідження у цьому напрямку матимуть справу із дихотоміями біологічного та соціального, індивідуального та колективного, одиниці проти популяції, мікрорівня та макрорівня аналізу [5]. Важливо також дослідити, як здорові харчові вибори пов'язані з іншими здоровими поведінковими виборами, як-то утримання від тютюнопаління, підтримання фізичної активності та використання пасків безпеки в автомобілі.

У докторській дисертації В. І. Шебанової [6] проблема психології харчової поведінки аналізується з позиції психосоматичної єдності. Досліджуються нормальні та патологічні прояви харчової поведінки людини. Доводиться, що «харчова поведінка як феноменологічне явище тілесності $\epsilon$ метасиндромним 
системно-процесуальним утворенням метакаузальної природи, що здатне до самоорганізації нелінійних зворотних зв'язків і саморозвитку в умовах хаотичного спонтанного структурування» [5, с. 37].

У книзі Дж. Нардоне, Т. Вербіц та Р. Міланезе [4] викладаються основи короткострокової терапії порушень харчової поведінки. Автори зосереджуються не на описовому, а на оперативному діагнозові, який дає змогу швидко та ефективно розібратися в проблемі та надати допомогу. Розробляються високопродуктивні протоколи роботи 3 людиною 3 розладом харчової поведінки; при цьому пропоновані протоколи є досить гнучкими та залежать від конкретних індивідуальнопсихологічних особливостей людини, яка звернулася за допомогою.

Книга Д. Перлмуттера «Їжа та мозок» [5] присвячена дослідженню взаємозв'язку між тим, що ми споживаємо, та роботою мозку та нервової системи. Грунтуючись на наукових студіях в галузі неврології та дієтології, автор доводить, що відмова від певних продуктів харчування може зарадити проблемам 3 пам'яттю, стресом, безсонням та поганим настроєм. Головними шкідливими речовинами Д. Перлмуттер називає глютен та вуглеводи. Відмовившись від них, можна значно покращити своє здоров'я та попередити розвиток небезпечних хвороб. Автор вважає найбільш доцільною систему харчування 3 високим вмістом жирів та низьким вмістом вугле- водів. I хоча така система видається занадто незвичною на перший погляд, Д. Перлмуттер переконливо показує іiі переваги для покращення стану мозку, психічного здоров'я та якості життя людини в цілому.

У книзі Ю. Лапіної «Тіло, їжа, секс та тривога» [3] підкреслюються історикокультурні корені ставлення до їжі та до тіла, зауважується, що досвід сприймання тіла та їжі сповнений помилкових стереотипів. Жінки часто стають жертвами таких помилкових уявлень, намагаючись втиснутись в неправильні шаблони чи досягти недосяжного. Ю. Лапіна підкреслює, що не варто тривожитися щодо тіла та їжі, адже зазвичай проблема 3 цими аспектами життя зовсім не в жінках, а обумовлюється модою, суспільними очікуваннями та несправедливими узагальненнями.

Виклад основного матеріалу дослідження.

Слід враховувати такі фактори впливу на харчову поведінку людини, як:

1. Культурні изінності. Слід розуміти, що культура у широкому значенні цього терміну $є$ основою усіх харчових виборів. Люди використовують категорії та правила своїх власних культур, субкультур, етнічних та професійних груп для окреслення того, що саме вони вважають прийнятною та/або найбільш вдалою їжею, обсяги та можливі поєднання обраних харчових продуктів, та види продуктів, традиційно позначувані як найкращі чи навпаки, заборонені. 
У плині того, як люди з більш традиційних суспільств (у т.ч. 3 українського) долучаються до харчової системи та засвоюють харчові патерни більш впливових західних суспільств, вони стикаються із явищем «харчового переходу», зазвичай прихильно сприймаючи та відтворюючи харчові моделі із вищим вмістом жирів порівняно з їх традиційною культурою. Головною рисою зазначеного переходу є поступовий зсув від споживання грубих зернових культур та продуктів з борошна в напрямку високоенергетичних жирів, насичених жирів та цукру [5]. Ця тенденція може проявлятися у формі смакооріснтованого бажання людини забезпечити собі більш різноманітну та калорійну дієту. По мірі того, як молоко, риба, свіжі овочі та фрукти включаються у таку дієту, відсоток споживаних жирів та цукрів також зростає. Явище харчового переходу також пов'язують 3 інтенсивною урбанізацією та дедалі більшою доступністю попередньо оброблених продуктів, багато 3 яких має підвищений вміст жирів, цукру та солі.

2. Сприйняття, переконання, установки та изіності. Люди вибудовують власні сприйняття, переконання та установки щодо їжі на основі культурних цінностей та психосоціальних факторів, які формують їх харчові вибори. Такі ширші культурні конструкції можуть не завжди співпадати зі строгими науковими поглядами на безпечність чи харчову поживність тих або інших продуктів. Напри- клад, сприйняття широким загалом ризиків обробки фруктів та овочів знезаражувальними хімікатами відрізняється від аналогічного сприйняття серед вчених-хіміків та спеціалістів-дієтологів, бо громадська думка має тенденцію до перебільшення небажаності зовнішніх, нечітких, неконтрольованих та техногенних ризиків, звертаючи набагато меншу увагу на ті ризики, щодо яких люди насправді мають та можуть робити вибір.

На соціальному рівні питання споживання їжі та харчової поведінки доволі рідко знаходяться серед найгостріших проблем суспільного порядку денного, хіба що ці питання драматичні, болючі та можуть мати значні наслідки. Перетворення певних харчових виборів на питання суспільного порядку денного далеко не завжди узгоджується 3 науковими моделями, оскільки ці питання є предметом впливу різних суспільних груп, які мають конкуруючі інтереси у наголошенні чи притлумленні тих або інших питань на поточному порядку денному [5]. У перебігу кількох останніх десятиліть просування ідеї про підвищене споживання жирів як про одну із суспільних проблем виявилося доволі успішним, аж до появи «жирофобії» серед певних прошарків суспільства. Подібна соціальна динаміка відображає важливу роль харчових виборів як питань порядку денного у сучасному суспільстBi.

3. Соціальні впливи. Людина здебільшого споживає їжу у присутності інших. Дослі- 
дження показують, що ефект соціальної фасилітації призводить до нижчого рівня споживання їжі наодинці і відповідно до вищого у обстановці групового споживання, особливо коли такі групи складаються зі знайомих між собою людей. Родина та друзі становлять головне джерело зразків для наслідування, i так само є основними факторами групового тиску у справі споживання тих чи інших харчів (включаючи продукти 3 підвищеним чи зниженим вмістом жирів) або куштування нових продуктів [1]. Родинна залученість є важливою для формування та подальшої підтримки харчових поведінкових змін, як це показано у дослідженнях щодо зниження ризиків серцево -судинних захворювань та щодо лікування надмірної ваги і пов'язаних із нею харчових розладів [9]. Очевидно, що брак соціальної підтримки здатний зруйнувати індивідуальні спроби харчових змін повністю чи принаймні критично зменшити успішність таких спроб.

4. ЗМI та реклама. Засоби масової інформації є одним із ключових джерел інформації про іжу та харчування для багатьох людей. Більшість рекламних бюджетів витрачають компанії, які виробляють упаковані солодкі та жировмісні продукти з високим рівнем обробки. Оскільки точні дані щодо обсягів продажу та відповідних рекламних витрат часто $є$ закритою комерційною інформацією, доволі проблематично встановити безпосередній зв'язок між рекламою та продажем. Однак численні свідчення підтверджують ефектив- ність рекламних повідомлень у збільшенні продажу харчових продуктів.

Окремою проблемою спеціалістидієтологи вважають рекламу, спрямовану на дітей. Ефективність маркетингових кампаній, спрямованих на молодші вікові групи, давно і добре відома виробникам алкогольних напоїв та тютюнових виробів. Реклама харчових продуктів має на меті збільшити впізнаваність бренду серед дитячої аудиторії, сформувати більш позитивне ставлення до споживання рекламованих харчових продуктів, створити у дітей мотивацію на прохання до батьків чи інших дорослих щодо придбання продукту тощо.

Рекламні повідомлення, які апелюють до «здорових» продуктів, зазвичай збільшують обсяги продажу. Використання таких маркетингових технологій, спрямованих на збільшення продажу харчових продуктів, позначених як «здорові», може однак викликати сумніви щодо відповідності таких методів. Продукт, що заявлений як «здоровий» у певному своєму аспекті (наприклад, з низьким вмістом жирів), цілком може бути доволі «нездоровим» у чомусь іншому (наприклад, містити багато солі чи цукру).

Чимало досліджень розглядали питання того, чи загрози або збудження страху у рекламних повідомленнях є ефективним засобом стимуляції споживачів до бажаних змін у харчовій поведінці. Узагальнений висновок цих робіт може бути сформульовано так, що 
як позитивні, так і негативні повідомлення мають значний вплив на формування та зміну харчової поведінки у короткостроковій перспективі, однак жодне повідомлення щодо харчування, іжі чи харчової поведінки не є однозначно ефективним, аби сформувати та підтримувати постійні зміни у харчовій поведінці людини [10].

5. Доступність. Для більшості людей харчові продукти, які вони хочуть чи хотіли би придбати, є вільно доступними. Завдяки інтенсивному розвитку харчової промисловості, продукти, які люди люблять та споживають, стають доступними у все більшому та ширшому розмаїтті варіантів. Однак слід розуміти, що термін «доступність» може мати різне значення для різних груп людей. «Всезагальна» доступність може бути описана як множина усіх харчових позицій, наявних та доступних для придбання покупцями, у т.ч. у плані фінансової доступності; а «моментальна» доступність відноситься до міри готовності та зручності споживання харчової продукції: «моментально доступні» продукти зберігаються довгий час без псування, вимагають незначний чи взагалі нульовий обсяг часу на підготовку та/або приготування страви, можуть бути спожиті будь-де, і розфасовані в індивідуальні упаковки.

Доступність харчових продуктів у публічній сфері (у ресторанах, кафе, школах, лікарнях, магазинах, їдальнях та на робочих місцях) залежить від низки взаємопов'язаних фа- кторів, як-то бюджет, відповідні умови зберігання та охолодження та вимог споживачів. Таким чином, певні продукти можуть виявитися відносно недоступними, чи доступними у малій кількості відносно загального обсягу доступних продуктів, чи доступними лише за завищеними цінами [8].

Хоча більший дохід людини не обов'язково призводить до покращень у якості харчування, фактор ціни виразно впливає на харчові вибори. Наприклад, більш коштовні продукти на кшталт червоної риби, дорогих сортів м'яса чи свіжих фруктів та овочів у зимовий сезон можуть бути менш доступними у бідних міських та сільських районах. Та навіть якщо такі продукти надходять у продаж, невисокі доходи місцевого населення все одно залишаються стримуючим фактором низької доступності.

6. Різноманіття. Різноманітні дієти часто асоціюються з вищим рівнем споживання корисних та поживних речовин і зниженими ризиками смерності та захворюваності. Люди, які споживають більше різноманіття харчів, зазвичай їдять більше. Однак різноманіття також може бути пов'язане із підвищеним споживанням жирів, цукру, солі чи холестерину. Збільшення різноманітності харчування у вужчому сенсі як збільшення споживання фруктів та овочів може як зменшувати, так i не зменшувати споживання висококалорійної їжі. Наприклад, споживання різноманітних фруктів та овочів не призводить автоматично 
до зменшення споживання жирів, аж поки людина сама не перестане їсти жирне м'ясо, смажені чи тушковані 3 високим вмістом жиру страви тощо.

7. Харчові вподобання. Більшість споживачів зазначають, що їх харчові вибори значною мірою визначаються смаком на противагу будь-яким міркуванням щодо поживності чи корисності. Поняття «смаку» у цьому випадку включає також запах та оральне сприйняття текстури страви. Сенсорні реакції-відповіді на смак, запах, зовнішній вигляд та текстуру харчових продуктів $є$ головним чинником впливу на харчові вподобання та звички [9]. Високоенергентичні продукти є найбільш бажаними у всіх географічних, етнічних, соціальних та культурних групах людей, і це може свідчити про те, що прагнення дорослої людської особистості до споживання жирів, цукру та солі є об’єктом фізіологічної регуляції.

Дослідження щодо вподобань жирної їжі серед людей та щурів пройшли чималу відстань від біології аж до складних поведінкових теорій. Збільшене споживання жирів пов'язують із генетичними мутаціями (лептин); зміненими рівнями галаніну, нейропептиду типу Y чи ендогенних опіатних пептидів у мозку; збільшенням маси тіла чи відсотку жиру у тілі; більшою масою тіла батьків; соціально наученими вподобаннями щодо висококалорійних продуктів; високою калорійністю жирної їі; розладом системи насичення; порушеннями циклу набору ваги (у щурів) та булі- мічним розладом (у людей); а також урбанізацією, збільшенням середнього доходу та зростанням ВВП.

Як свідчать дослідження [9], оральне сприйняття жирності харчових продуктів здебільшого регулюється почуттями запаху та текстури. Сенсорна реакція на жир визначається також текстурою страви у процесі жування та ковтання. Оральні сприйняття жиру залежать від типу їжі: м'ясна чи молочна, рідка чи тверда, сира чи печена. Наприклад, жир у молочних продуктах набуває форми жирових кульок, які сприймаються на смак як м'які та ніжні. Здатність жиру зв'язувати молекули води відповідає за ніжність та соковитість стейків, м'якість пирогів та печива. Термічні перетворення при високих температурах створюють хрумкі, хрусткі та ламкі текстури їжі. Загалом жировмісні продукти сприймаються більш різноманітними, привабливими, запашними, багатими на смак та поживними.

Вподобання щодо солодкої їжі є вродженим та універсальним для більшості людей [7]. Людські новонароджені діти показують позитивну гедоністичну відповідь на солодкі розчини. Харчові вподобання дітей молодшої вікової групи (3-5 років) значною мірою визначаються солодкістю та знайомим смаком. Молодші діти також люблять дуже підсолоджені розчини цукру з концентрацією аж до $20 \%$ за масою. Сенсорні вподобання щодо солодких напоїв зменшуються 3 віком, трохи більше серед дівчат, аніж серед хлопчи- 
ків.

Дитячі вподобання жирної та солодкої їжі можуть змінюватися відповідно до пережитого досвіду. Смакові вподобання щодо жирів набуваються зразу після народження або у ранньому дитинстві. Вроджене вподобання жирів є менш імовірним, бо жири надають різних текстальних властивостей різним харчовим продуктам: жир робить морозиво ніжним та вершковим на смак, гамбургер соковитим, а випічку - пишною. Жир також працює як транспортер смаку для жиророзчинних молекул, які створюють відчуття смаку. Так, жири, які знаходяться у рідкому стані при температурі ротової порожнини, переносять такі молекули дуже ефективно (наприклад, соняшникова чи оливкова олія).

Смакові реакції-відповіді мають прямий вплив на споживання їжі у дітей, оскільки діти зазвичай їдять більше такої їжі, яку вони люблять найбільше, і відмовляються від тієї, яка їм не подобається за смаком чи текстурою. У дорослому віці навпаки, зв'язок між смаковими вподобаннями та споживанням харчових продуктів є менш безпосереднім та чітко вираженим. Дорослі не обов'язково прирівнюють солодкий смак до позитивних харчових якостей, у цьому віці харчові вподобання чи невподобання вже не завжди співпадають 3 патернами споживання їжі. Застереження щодо здоров'я, маси тіла та зовнішнього вигляду можуть призводити до харчових обмежень, уникання жирів та цукру, та збільшення част- ки «здорових», однак непривабливих у інших аспектах харчових продуктів. Цей конфлікт між когнітивним та сенсорним факторами у дорослих $є$ темою багатьох досліджень з старіння, надмірної ваги та харчових розладів.

Харчові вподобання можуть різнитися залежно від статі. Чоловіки з надмірною вагою віддають перевагу м'ясним стравам та іншим комбінаціям жирів та протеїнів, жінки у аналогічному становищі переважно обирають солодкі десерти, шоколад, морозиво та інші різноманітні суміші жирів та цукру. Схожі поведінкові та вподобальні патерни спостерігаються і серед жінок та чоловіків із нормальною вагою.

8. Соціальне научіння. Хоча научіння щодо їжі та харчових продуктів триває протягом усього людського життя, найважливіші події трапляються протягом перших п'яти років дитинства. Цей період включає в себе перехід від суцільномолочної дієти, багатої на жири (понад 50\% споживаної дитиною калорійності забезпечується у цей час молочними жирами), до дієти із нижчим сукупним вмістом жирів. Наразі дієтологи рекомендують [2], аби діти передшкільного віку отримували 30 \% калорій зі спожитих жирів. Вказаний перехід також передбачає навчання споживати чималий перелік рідкої та твердої їжі [3].

Навчання харчовій поведінці у ранньому дитинстві обмежене генетичними схильностями дітей та їх попереднім досвідом молочної дієти. Такі схильності передбачають нега- 
тивну вподобальну реакцію на кислі та гіркі смаки. Батьки інтерпретують смакомімічні реакції немовлят на основні види смаків як відображення вподобань чи невподобань, використовуючи це як основний визначник для підбору харчових продуктів для своєї дитини. Молодші діти схильні відмовлятися від нової їжі (харчова неофобія), однак ця типова реакція може бути модифікована шляхом створення повторюваних можливостей спробувати нові страви. Кількість та якість різноманітного харчового досвіду у ранньому дитинстві забезпечує створення основи для научіння щодо їжі та правильної харчової поведінки, та є критично важливим у формуванні смакових уподобань та смакових виборів дитини. Повторювані можливості скуштувати нову страву можуть перетворити початково невподобану нову їжу на нейтральну, а з часом навіть на улюблену.

Аналіз способів презентації жировмісної їжі дітям, особливо у розрізі соціальних контекстів та пост-споживальних поведінкових наслідків, відкриває чимало можливостей для формування та зміни вподобань такої їжі [6]. Наприклад, жировмісні продукти можуть стати улюбленими, коли показуються у позитивному контексті (як заохочення); є невід'ємною частиною родинних святкувань та урочистостей; або комбінуються з іншими улюбленими чи вподобаними смаками. Важливим також $є$ вподобання жирної та висококалорійної їжі іншими членами родини, які виступають рольовими моделями для малої дитини. Калорійні та жирні страви також створюють позитивне відчуття насичення, що може працювати як безумовний стимул для научуваних вподобань. Занадто часте повторення ситуацій, де продукти, багаті на цукор, жир та сіль, виступають у ролі нагород чи заохочень, може навіть призводити до порушення базових психосоціальних функцій їжі як такої. Тому батьки заздалегідь можуть навчити власних дітей обережному та виваженому ставленню до таких продуктів, які слід споживати у обмежених обсягах.

Відчуття відрази та невподобання також формуються у ранньому дитинстві. Навіть одноразове виникнення нудоти чи набряку одночасно 3 певним смаком здатне спричинити відразу до певного продукту; вподобальні реакції-відповіді на солодкі та солоні смаки продуктів теж можуть мінятися з урахуванням пережитого досвіду. Більше того, їжа, споживана для того, аби дістати якусь нагороду (зазвичай іншу їжу, яка сприймається як смачніша та бажаніша), швидко стає невподобаною.

Навчені вподобання щодо калорійної їжі спершу демонструвалися у експериментах з лабораторними щурами, а потім 3 дітьми молодшої вікової групи. Коли дітям надавали повторювану можливість спожити або висококалорійну, зі значним вмістом жиру, страву, або ж їі знежирену та низькокалорійну версію, учасники експерименту швидко навчалися 
віддавати перевагу висококалорійним продуктам перед низькокалорійними версіями тієї самої їжі, притому такі вподобання особливо чітко виявлялися тоді, коли діти були голодними.

Калорійність також впливає на обсяги споживаної дітьми їжі. Дослідження показують [3], що немовлята та молодші діти здатні регулювати обсяги споживання їжі у відповідь на зміни в калорійності споживаних продуктів. Хоча обсяг споживання у межах одного окремо взятого прийому їжі може бути нестабільним, однак у межах 24-годинного циклу калорійність споживання виявляється доволі добре регульованою величиною. Індивідуальні відмінності у саморегуляції калорійності зазвичай пов'язують 3 відмінностями у досвіді дитячого годування та 3 надмірною масою тіла батьків дитини. Крім того, пропонування дітям продуктів із помірним вмістом жирів ще не гарантує успішного споживання. Таким чином, практики годування дітей демонструють значний потенціал щодо зміни енергетичного балансу організму шляхом впливу на харчові вподобання, харчові вибори та обсяги спожитої їжі.

Впровадження суворого батьківського контролю може спровокувати розвиток вподобань жирної, висококалорійної їжі, обмежити вибір дитини у сприйнятті харчового різноманіття та порушити харчову саморегуляцію дитини через ігнорування внутрішніх сигналів голоду та насичення. Такі реакції можуть мати місце у випадках, коли батьки переконані, що дітям потрібна допомога та настанова у визначенні того, що, коли та як багато вони мають спожити, та впроваджують такі практики харчування, де дітям залишається мало можливостей для самоконтролю.

Глибше розуміння факторів, які впливають на харчові вподобання дітей, включно із вподобаннями жирної та висококалорійної їжі, може пояснити, яким чином у дорослих формуються патерни харчової поведінки, несумісні з порадами спеціалістів-дієтологів та запропонувати альтернативні механізми профілактичних інтервенцій, які могли би сформувати більш здорові поведінкові патерни.

9. Знання. Люди можуть використовувати власні знання для формування когнітивних зв'язків між харчуванням та здоров'ям, змінюючи таким чином власну поведінку, але саме по собі знання не є завжди ефективним [7]. В сучасному світі інформація щодо здорового способу життя та харчових ризиків є вільно доступною найширшим прошаркам населення, однак багато людей або не знають, як застосовувати цю інформацію у повсякденному житті, або недостатньо мотивовані до реальних змін власної харчової поведінки.

Учасники опитувань схильні применшувати обсяги власного щоденного споживання їжі, хоча й не завжди зумисне, притому таке применшення $є$ більш вираженим поміж респондентів із надмірною вагою. Люди також схильні до помилкових уявлень щодо об- 
сягів жиру та калорій у багатьох найпопулярніших продуктах, що містяться у їх повсякденних раціонах. Таким чином, у аспекті інформаційного впливу на поширення «здорових» моделей харчування слід визнати, що поінформованість далеко не завжди є запорукою значного впливу на реальну харчову поведінку людини.

\section{Висновки та перспективи подальших} досліджень. Отже, ми проаналізували низку факторів, які впливають на харчову поведінку людини, та виокремили головні, ключові чинники, які необхідно враховувати в психологічній допомозі людям з розладами харчової поведінки. Серед цих факторів чільне місце займають культурні фактори та особливості переконань і установок людини щодо їжі. Важливу роль відіграють соціальні впливи - людина може захотіти спожити інші продукти під дією того, що хтось із оточення споживає їх теж. Інколи позитивний, але здебільшого все ж негативний вплив мають засоби масової інформації та реклама, часто стимулюючи нездорові харчові вибори. Слід враховувати також такі характеристики продуктів, як їх доступність та різноманіття, які можуть сильно впливати на харчову поведінку особистості. Численні дослідження вказують також на важливу роль соціального научіння та знань про те, яка їжа є здоровою, правильною, корисною. Проведений нами теоретичний аналіз дав змогу виокремити різні групи факторів - від культурних цінностей до специфіки продуктів харчування. Проведене теоретичне дослідження може допомогти в психологічній підтримці людей з розладами харчової поведінки.

Перспективи подальших досліджень пов'язані з емпіричним дослідженням психологічних факторів, які впливають на харчову поведінку жінок репродуктивного віку.

\section{Перелік використаних джерел:}

1. Абсалямова Л. М. Дослідження харчових виборів жінок репродуктивного віку / Л.М. Абсалямова // Проблеми сучасної психології: Збірник науковихпраць Кам'янець-Подільського національного університету імнеі Івана Огієнка, Інституту психології імені Г. С. Костюка НАПН України / за наук. ред. С. Д. Максименка, Л. А. Онуфрієвої. - Вип.39. - КамянецьПодільський: Аксіома, 2018. - С.19-31.

2. Абсалямова Л. М. Психологія харчової поведінки людини / Л.М. Абсалямова. - Харків: Видавництво «Смугаста типографія», 2017. - 181 с.

3. Лапина Ю. Тело, еда, секс и тревога: Что беспокоит современную женщину. Исследование клинического психолога / Ю. Лапина. - М.: Альпина нон-фикшн, 2018. - 229 c.

4. Нардонэ Дж. В плену у еды: булимия, анорексия, vomiting. Краткосрочная терапия нарушений пищевого поведения. Пер. с итал. О.Е. Игошиной / Нардонэ Дж., Вербиц Т., Миланезе Р. - М.: Генезис, 2016. - 320 с.

5. Перлмуттер Д. Еда и мозг. Что углеводы делают со здоровьем, мышлением и памятью / Д. Перлмуттер. М.: Манн, Иванов и Фербер, 2017. - 240 с.

6. Шебанова В. I. Психологія харчової поведінки / В.I. Шебанова. - Автореф. дис... доктора психол. наук. К., 2017. - 40 c.

7. Шнаккенберг Н. Мнимые тела, подлинные сущности: Преодоление конфликтов идентичности с внешностью и возвращение к подлинному Я / Н. Шнаккенберг. Пер. 
с англ. - Калининград: Phoca Books, 2017. - 376 c.

8. Hoorens $V$. Social comparison of health risks: locus of control, the person positivity bias, and unrealistic optimism / V. Hoorens, B. Buunk. // Journal of Applied Social Psychology. - 1993. - №23. - C. 291-302.

9. Oenema A. Exploring the occurrence and nature of comparison of one's own perceived dietary fat intake to that of self-selected others / A. Oenema, J. Brug // Appetite. 2003. - №41. - C. 259-264.

10. Promoting healthy diet and exercise patterns amongst primary school children: a qualitative investigation of parental perspectives / K.Hart, A. Herriot, J. Bishop, H. Truby // Journal of Human Nutrition and Dietetics. - 2003. №16. - C. 89-96.

\section{References (Transliteration):}

1. Absaljamova L. M. Doslidzhennja harchovih viboriv zhinok reproduktivnogo viku / L.M. Absaljamova // Problemi suchasnoï psihologiï: Zbirnik naukovihprac' Kam'janec'-Podil's'kogo nacional'nogo universitetu imnei Ivana Ogienka, Institutu psihologiï imeni G. S. Kostjuka NAPN Ukraïni / za nauk. red. S. D. Maksimenka, L. A. Onufrievoï. - Vip.39. - Kamjanec'-Podil's'kij: Aksioma, 2018. - S.19-31.

2. Absaljamova L. M. Psihologija harchovoï povedinki ljudini / L.M. Absaljamova. - Harkiv: Vidavnictvo «Smugasta tipografija», 2017. - $181 \mathrm{~s}$.

3. Lapina Ju. Telo, eda, seks i trevoga: Chto bespokoit sovremennuju zhenshhinu. Issledovanie klinicheskogo psihologa / Ju. Lapina. - M.: Al'pina non-fikshn, 2018. - 229 s.

4. Nardonje Dzh. V plenu u edy: bulimija, anoreksija, vomiting. Kratkosrochnaja terapija narushenij pishhevogo povedenija. Per. s ital. O.E. Igoshinoj / Nardonje Dzh., Verbic T., Milaneze R. - M.: Genezis, 2016. - 320 s.

5. Perlmutter D. Eda i mozg. Chto uglevody delajut so zdorov'em, myshleniem i pamjat'ju / D. Perlmutter. - M.: Mann, Ivanov i Ferber, 2017. - 240 s.

6. Shebanova V. I. Psihologija harchovoï povedinki / V.I. Shebanova. - Avtoref. dis... doktora psihol. nauk. - K.,
2017. $-40 \mathrm{~s}$.

7. Shnakkenberg N. Mnimye tela, podlinnye sushhnosti: Preodolenie konfliktov identichnosti s vneshnost'ju i vozvrashhenie k podlinnomu Ja / N. Shnakkenberg. Per. s angl. - Kaliningrad: Phoca Books, 2017. - 376 c.

8. Hoorens $V$. Social comparison of health risks: locus of control, the person positivity bias, and unrealistic optimism / V. Hoorens, B. Buunk. // Journal of Applied Social Psychology. - 1993. - №23. - S. 291-302.

9. Oenema A. Exploring the occurrence and nature of comparison of one's own perceived dietary fat intake to that of self-selected others / A. Oenema, J. Brug // Appetite. 2003. - №41. - S. 259-264.

10. Promoting healthy diet and exercise patterns amongst primary school children: a qualitative investigation of parental perspectives / K.Hart, A. Herriot, J. Bishop, H. Truby // Journal of Human Nutrition and Dietetics. - 2003. №16. - S. 89-96.

\section{Absalyamova Larysa}

PhD in psychological sciences, associate professor at the department of practical psychology, H. S. Skovoroda Kharkiv National Pedagogical University, Kharkiv (Ukraine)

\section{PSYCHOLOGICAL ANALYSIS OF FACTORS INFLUENCING PERSON'S DIE- TARY BEHAVIOR}

\section{ABSTRACT}

The psychological analysis of factors influencing on human food behavior and food choices is presented in the article. It is noted that problem of analysis of main factors of human food behavior is very actual, as far as it can become the basis for effective psychotherapy interventions and psychological support of personality who plans to change his/her food behavior or is already in the process of such changes. The article presents researches of different factors in 
forming of human food behavior, that show that food likes and unlikes are the core of development, support and change of food patterns.

Food behavior is continuously obtained during all cource of a human life, and that is why changes in such behavior require forming of repeated habits, that must be similarly protracted; such duration is fundamentally more longstanding than any short-term intervention periods. Dietary recommendations intended to reduce fat consumption often induce avoidance of separate products or even whole food categories, and consequently are mostly perceived as superfluously burdensome.

Different influence factors on human food behavior are studied in the article, from psychophysiologycal to social and cultural. Special accents are made on duration of human food behavior, its necessity for everyday life, and, accordingly, meaningfulness for psychological prosperity of a person. Such factor of influence on food behavior as cultural values is also analysed. It develops research into a space of modern trends of psychological science, where cultural and historical determinants should be taken into account.

Such factors, as perception, attitudes, beliefs and values, are investigated. Thus investigated scope of problems becomes linked not only to achievements of cognitive psychology but also actually transcends into dimension of real everyday life of a person and psychological help to a person, who is internally ready to make changes in food behavior. The conclusion is made about the necessity to account different factors of influence on human food behavior in the process of psychological work of a professional with a client, who decided to change certain aspects of his/ her own food behavior, optimizing own psychological health and prosperity.

Key words: food behavior, personality, food choice, food behavior disorders, food behavior change.

\section{Абсалямова Лариса Николаевна}

Кандидат психологических наук, доиент, доиент кафедры практической психологии, Начиональный педагогический университет имени Г. С. Сковороды, г. Харьков (Украина)

\section{ПСИХОЛОГИЧЕСКИЙ АНАЛИЗ ФАКТОРОВ, ВЛИЯЮЩИХ НА ПИЩЕВОЕ ПОВЕДЕНИЕ ЧЕЛОВЕКА}

Аннотация. В статье представлен психологический анализ факторов, влияющих на пищевое поведение и пищевые выборы человека. Отмечается, что проблема анализа факторов влияния на пищевое поведение человека является актуальной, поскольку может стать основой для эффективных психотерапевтических интервенций и психологического сопровождения личности, которая планирует изменять пищевое поведение или же находится в процессе таких изменений.

Пищевое поведение непрерывно приобретается в течение всей жизни человека, и потому изменения в таком поведении требуют формирования повторяемых привычек, кото- 
рые должны быть такими же длительными; подобная длительность является принципиально длительнее любых краткосрочных периодов интервенций. Диетологические наставления, направленные на уменьшение потребления жиров, часто побуждают к избежанию отдельных продуктов или даже целых пищевых категорий, и следовательно по большей части воспринимаются как излишне обременительные.

Изучаются разные факторы влияния на пищевое поведение личности, от психофизиологических до социальных и культурных. Сделан акцент на продолжительности пищевого поведения человека, необходимости в повседневной жизни, и, соответственно, значимости для психологического благополучия личности. Анализируется такой фактор влияния на пищевое поведение, как культурные ценности. Это выводит исследование в пространство современных тенденций психологической науки, в пределах которой важно учитывать культурно-исторические детерминанты.

Исследуются такие факторы, как восприятие, установки, убеждения и ценности. Это связывает исследуемую проблематику не только с достижениями когнитивной психологии, но и фактически выводит в пространство реальной жизни человека и психологической помощи личности, внутренне готовой к изменениям в пищевом поведении. Делается вывод о необходимости учёта разных факторов влияния на пищевое поведение человека в процессе психологической работы профессионала с личностью, которая решила изменить определенные аспекты собственного пищевого поведения, тем самым оптимизируя собственное психологическое здоровье и благополучие.

Ключевые слова: пищевое поведение, личность, пищевой выбор, расстройства пищевого поведения, изменения пищевого поведения.

\footnotetext{
Дата отримання статті: 24.05 .2018 Дата рекомендації до друку: 15.06.2018 Дата оприлюднення: 02.07.2018
} 